Proc. Estonian Acad. Sci. Biol. Ecol., 2004, 53, 4, 283-291

\title{
Comparison of macrozoobenthic communities between the 1960s and the 1990s-2000s in the Väinameri, NE Baltic Sea
}

\author{
Helen Orav-Kotta*, Jonne Kotta, and Ilmar Kotta \\ Estonian Marine Institute, University of Tartu, Mäealuse 10a, 12618 Tallinn, Estonia \\ Received 10 March 2004, in revised form 2 September 2004
}

\begin{abstract}
Macrozoobenthic communities were studied in the Väinameri archipelago sea during the summers of 1993-2003. When comparing these data with the historical observations from the 1960s the following conclusions were drawn. (1) During the last 30 years the crustaceans Gammarus locusta, Leptocheirus pilosus, Monoporeia affinis, Bathyporeia pilosa, and Idotea baltica and the polychaetes Harmothoe sarsi and Pygospio elegans have disappeared or their densities have decreased considerably. (2) The majority of these changes were due to the hydrological changes during last 30 years. The decreasing salinity resulted in the disappearance of G. locusta, H. sarsi, and P. elegans and a reduction of the distribution of $B$. pilosa. (3) The general increase in the eutrohpication of the Baltic Sea had no effect on the species composition of macrozoobenthos whereas on average a fourfold increase in the biomass was observed. (4) The North-American polychaete Marenzelleria viridis invaded the Väinameri in 1995. However, the species has failed to establish at high densities in the study area.
\end{abstract}

Key words: Baltic, distribution, Furcellaria, macrozoobenthos, Marenzelleria, temporal changes.

\section{INTRODUCTION}

The Väinameri contains a large number of different habitats and has a high benthic diversity as compared to other regions in the northeastern Baltic Sea. Very high productivities of benthic vegetation and invertebrates have been documented in the region (Järvekülg, 1970). The entire area is shallow emphasizing the importance of benthic macroalgae for the dynamics of macrozoobenthos. An extensive part of the Väinameri is covered by a rare assemblage of the loose-lying macroalga Furcellaria lumbricalis (Trei, 1970). In spite of the

\footnotetext{
*Corresponding author, helen.orav@ sea.ee
} 
fact that the invertebrate and macroalgal assemblages are relatively well described (Järvekülg, 1970; Trei, 1970; Kotta \& Orav, 2001) there is no information on temporal trends in the benthic communities of the Väinameri.

Based on the earlier investigations by Järvekülg (1970) a comparison of benthic invertebrate communities between the 1960 s and the 1990s-2000s was made. Using available data on the tolerance of benthic invertebrate species to various environmental variables we tried to demonstrate the relative importance of climatic and anthropogenic processes in the changes of benthic communities in the Väinameri area.

\section{MATERIAL AND METHODS}

This mapping study was carried out in the Väinameri archipelago sea (Fig. 1) in 1993-2003. As phytobenthic assemblages are best developed in August

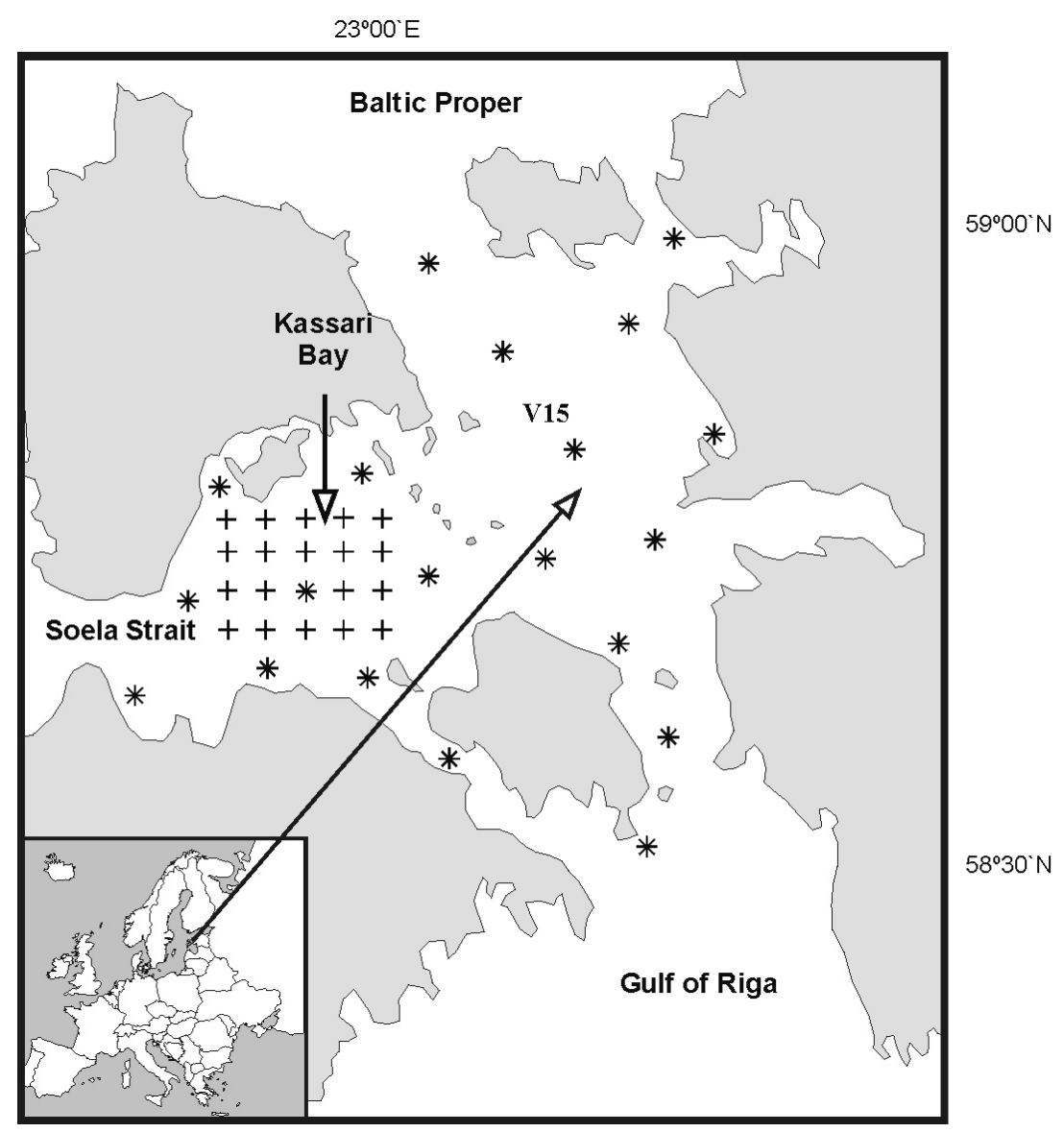

Fig. 1. Study area and sampling stations indicated by crosses, stars, or V15. Stars show the stations where additional grab samples were taken in 1993-2003. 
(TemaNord, 1996), the mapping was done during that time of the year. Samples were collected with a Tvärminne sampler (catching surface $315 \mathrm{~cm}^{2}$ ) on silt, sand, or gravel bottoms and with a core sampler (catching surface $175 \mathrm{~cm}^{2}$ ) on boulders and limestone in 1995-2003 (indicated by stars and crosses in Fig. 1). Samples below $0.5 \mathrm{~m}$ were taken by SCUBA diving. Additional 20 samples were collected all over the Väinameri (uniform sampling design, indicated by stars in Fig. 1) by a modified Petersen grab annually in 1993-1996. A van Veen grab was used at station V15 in 1993-2003. The grab sampling was used also in the 1960s (Järvekülg, 1970). This allows us to make a temporal comparison of benthic invertebrate communities between the 1960s and the 1990s-2000s. During sampling the sediment type (stone, boulder, pebble, gravel, coarse sand, medium sand, fine sand, silt, clay, or mixed) and depth were recorded. The coverage of phytobenthos, dominant species, and thickness of the algal canopy were estimated by a diver. The material was sieved through a net of $0.25 \mathrm{~mm}$ mesh size and then deep frozen at $-20^{\circ} \mathrm{C}$. In the laboratory all animals were counted under a binocular microscope. Dry weights were obtained (accuracy $\pm 0.1 \mathrm{mg}$ ) after drying the material at $60^{\circ} \mathrm{C}$ for $48 \mathrm{~h}$. Molluscs were weighed with shells.

\section{RESULTS}

Of the species recorded in the 1960s we failed to find Monoporeia affinis, Gammarus locusta, Leptocheirus pilosus, Harmothoe sarsi, Pygospio elegans, and Bithynia tentaculata in the study area during the 1990s-2000s. Besides, Bathyporeia pilosa and Idotea baltica had significantly reduced their distribution area (Fig. 2). In the 1960s all these species occurred practically around the whole Väinameri and had relatively high densities (Järvekülg, 1970).

No significant differences in the distribution area of Hediste diversicolor, Corophium volutator, Jaera albifrons, Hydrobia ulvae, Macoma balthica, Mya arenaria, Mytilus edulis, and Cerastoderma glaucum were observed between the 1960s and the 1990s-2000s. Like in the 1960s these bivalves constituted the highest proportion of the zoobenthic biomass also nowadays (Fig. 3). The spatial distribution of areas with a high benthic biomass have remained similar; however, a fourfold increase in the average macrobenthic biomass was observed. In the 1960s the average benthic biomass was $23 \mathrm{~g} \mathrm{dw} \mathrm{m}^{-2}$ and the maximum biomass was $103 \mathrm{~g} \mathrm{dw} \mathrm{m}^{-2}$, in the 1990s-2000s the values were $101 \pm 12$ and $1075 \mathrm{~g} \mathrm{dw} \mathrm{m}^{-2}$, respectively. The highest benthic biomasses were observed in the areas that were covered by a loose-lying mat of $F$. lumbricalis. In these sites M. edulis always prevailed. At the sites with high biomasses the number of macrobenthic species did not differ from the adjacent sites.

Among newcomers the North American polychaete Marenzelleria viridis was observed in the Väinameri since 1995. In 1996-1999 the density of the species was relatively high. It was mainly found in the middle part of the Väinameri (Kassari Bay) with its distribution area coinciding with the distribution area of the loose-lying alga $F$. lumbricalis. Since 2000 the species has disappeared in the 

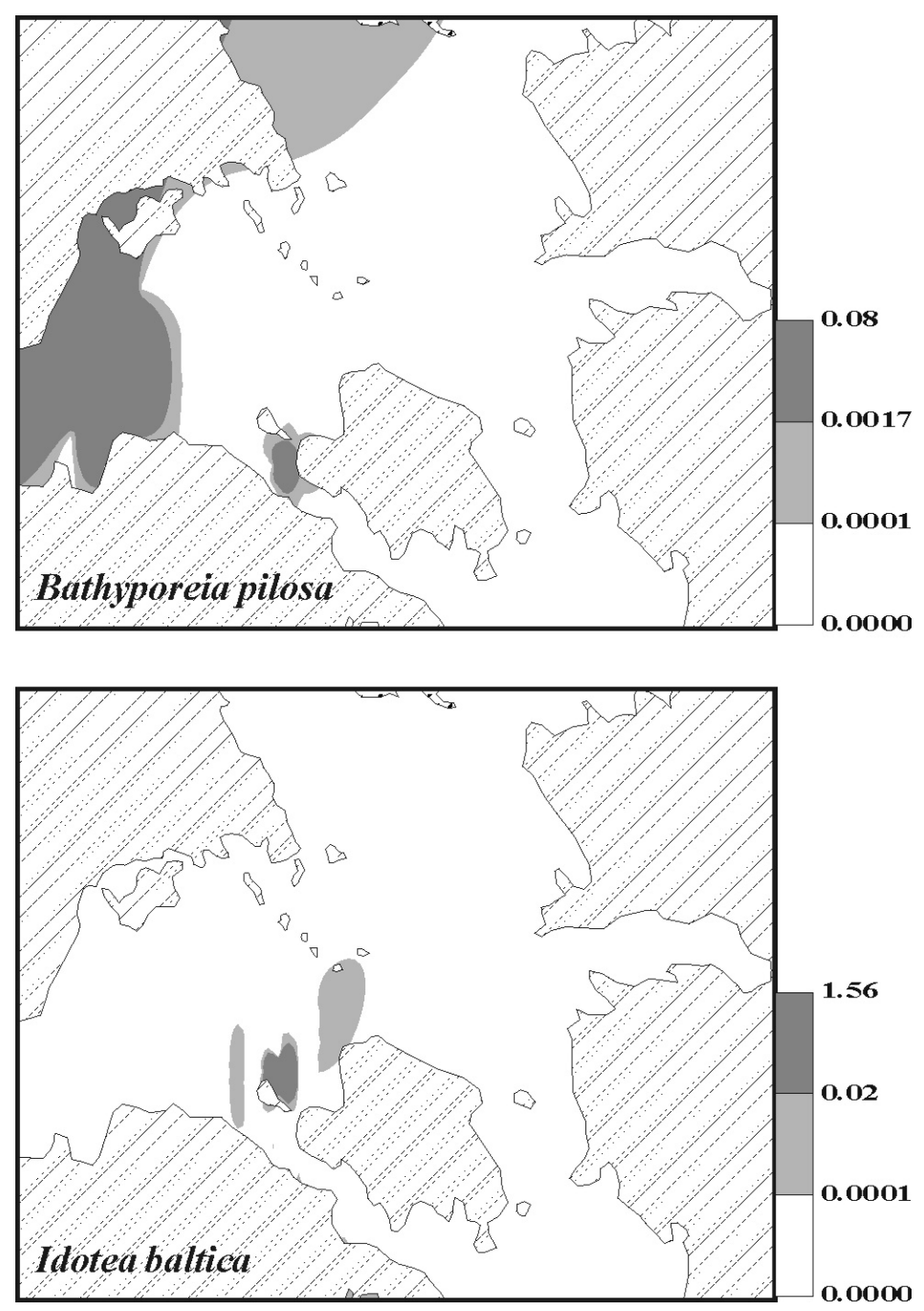

Fig. 2. Average biomass distribution $\left(\mathrm{dw} \mathrm{m}^{-2}\right)$ of Balthyporeia pilosa and Idotea baltica in the Väinameri in the 1990s-2000s. The values in the scale bar show the variability in biomass values. Lowest, intermediate, and highest ranges refer to equal shares of biomass distribution.

shallower areas of the Väinameri and in Kassari Bay. At the deeper sites, however, $M$. viridis has been observed occasionally but at densities below 10 ind $\mathrm{m}^{-2}$ (station V15).

In the last ten years the structure of benthic invertebrate communities has been relatively stable and the marine suspension feeders, mainly M. edulis, have prevailed in the area. A notable reduction in the benthic biomass can be observed during this period (Figs. 4 and 5). 

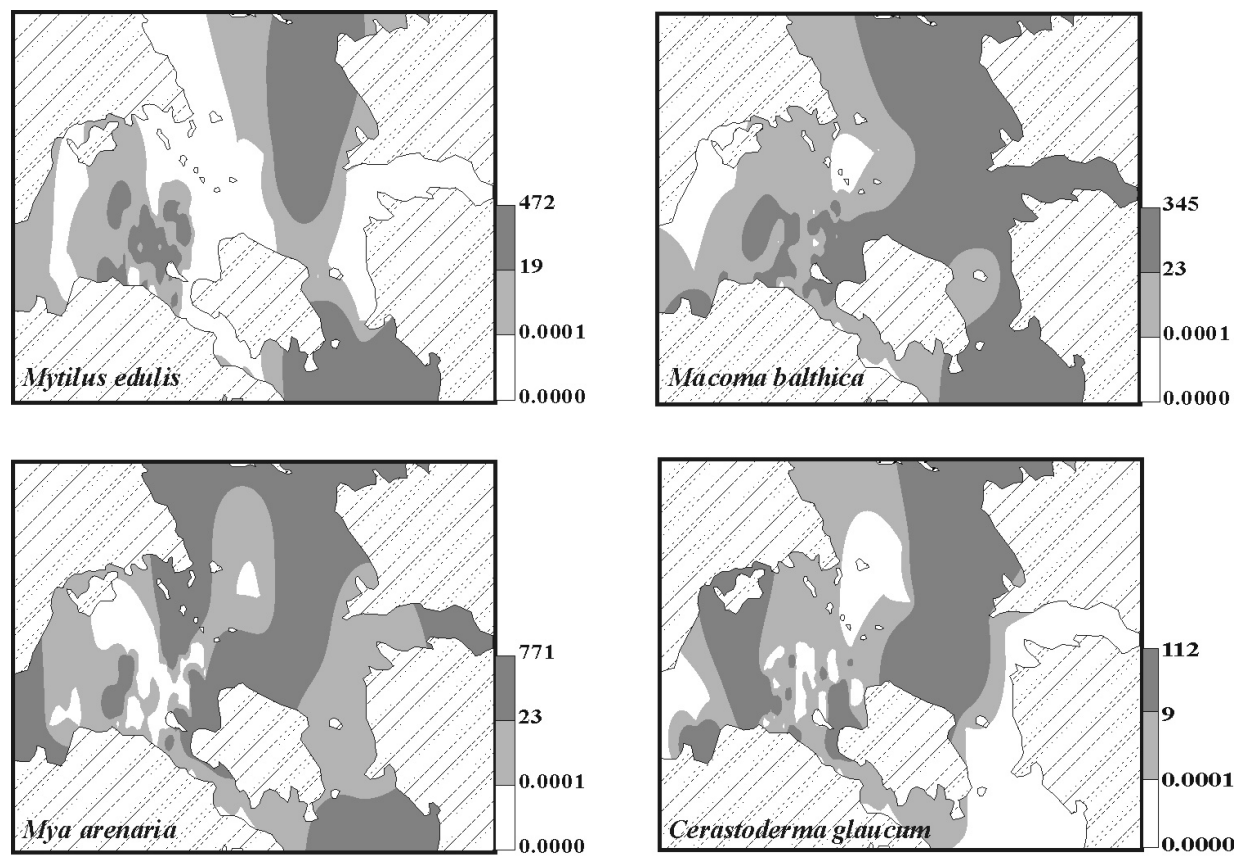

Fig. 3. Average biomass distribution $\left(\mathrm{dw} \mathrm{m}^{-2}\right)$ of bivalves in the Väinameri in the 1990s-2000s. The values in the scale bar show the variability in biomass values. Lowest, intermediate, and highest ranges refer to equal shares of biomass distribution.

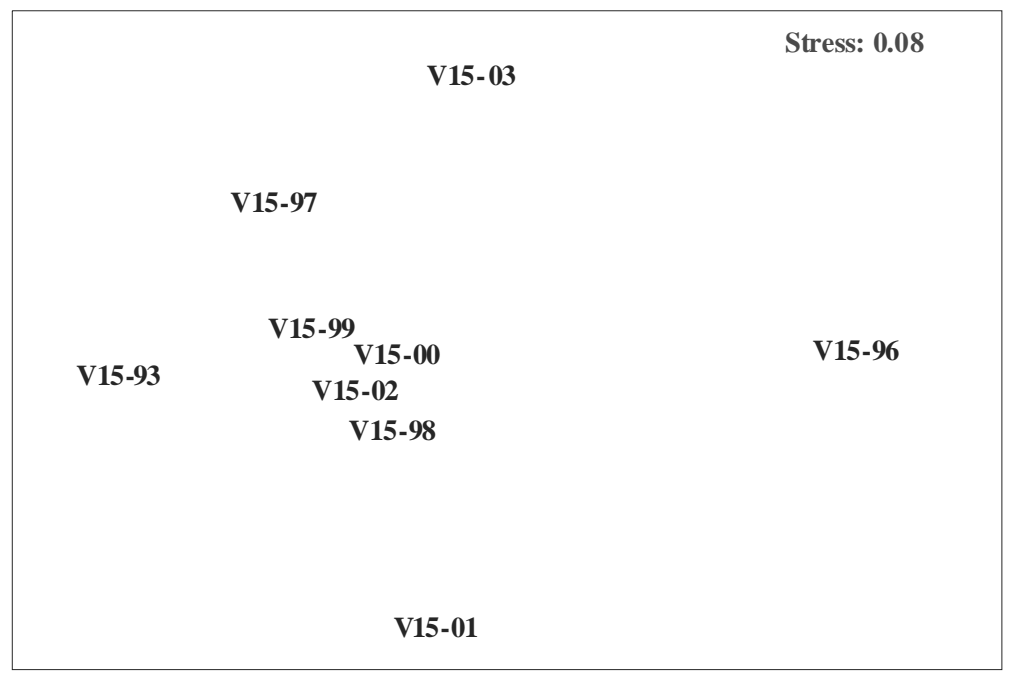

Fig. 4. MDS ordination of macrozoobenthic biomasses at station V15 in 1993-2003. The station code includes the relevant year. The distance between the samples represents the differences in the community structure. 

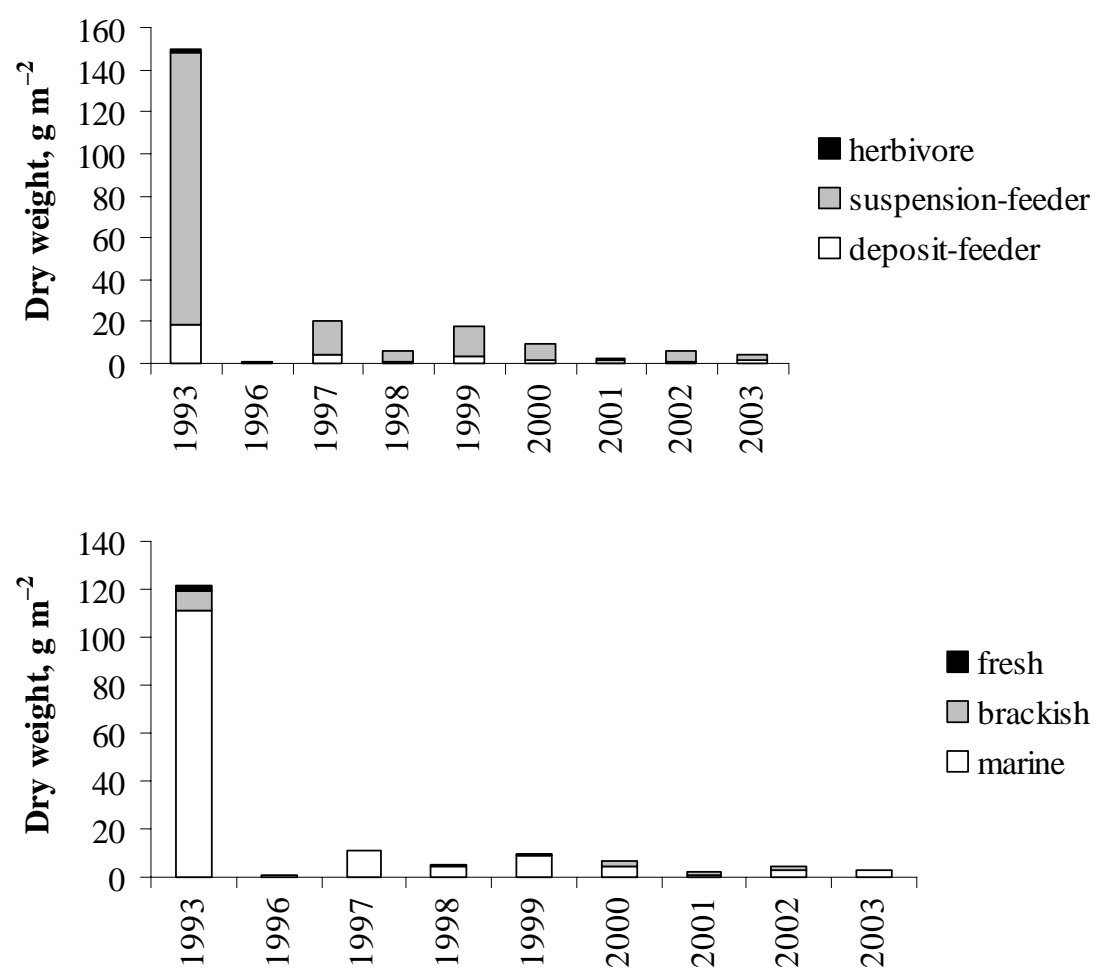

Fig. 5. Biomass of different macrozoobenthic functional groups at station V15 in 1993-2003.

\section{DISCUSSION}

Our results indicate that three crustaceans, two polychaete species, and one gastropod species have disappeared in our study area during the last 30 years. It is important to stress here that the sampling was done in summer when the water temperature was higher than the optimum values for M. affinis and H. sarsi. Therefore, it is likely that these species may occasionally invade the study area during colder seasons. However, the timing of the sampling did not differ between our study and that of Järvekülg (1970). This suggests that either the reduction of salinity, the increasing summer temperatures, or both factors may be behind this disappearance. According to the database of the Estonian Marine Institute the average salinity has decreased about $0.5 \mathrm{PSU}$ and the average water temperature in summer has increased about $1{ }^{\circ} \mathrm{C}$ in the Väinameri from the 1960 s to the present day. As $P$. elegans and $H$. sarsi originate from marine areas, the salinity reduction may explain their disappearance.

The disappearance of M. affinis and B. tentaculata may be related to the general increase of the eutrophication level in the study area. The increased accumulation of organic matter and the excessive growth of filamentous algae (Martin et al., 2003) 
result temporarily in poor oxygen conditions, which are disadvantageous to the named species (Yarvekyulg, 1979; Sandberg, 1996).

As compared to other cleaner bays of the Estonian coastal sea (Kotta \& Kotta, 1997, 1998; Kotta et al., 1999; Ojaveer et al., 1999; Kotta, 2000), the Väinameri is the only location where the establishment of the North American polychaete $M$. viridis was initially very successful. In the study area the abundances of $M$. viridis do not reach the values of the eutrophicated bays of the southern Baltic Sea (e.g. Zettler, 1997), which may reflect strong temporal and spatial gradients of temperature, salinity, and oxygen in the northern Baltic Sea.

Depending on the geographic area the polychaete newcomer's effect on the native fauna differs. There has been some evidence that the Baltic M. viridis reduces the densities of the shallow water amphipod $C$. volutator (Atkins et al., 1987; Zettler, 1996), the polychaete $H$. diversicolor (Atkins et al., 1987; Essink \& Kleef, 1993), and the deep-water amphipod M. affinis (Cederwall et al., 1999). The observations are supported by the experimental evidence that there is competition for food between $M$. viridis, $H$. diversicolor, and M. affinis (Kotta et al., 2001; Kotta \& Ólafsson, 2003). In the North Sea, however, the dynamics of the benthic communities suggests that an empty niche was still available for the newcomer Marenzelleria wireni and the polychaete does not compete with the native animals (Essink et al., 1998; Essink, 1999).

In the Väinameri $M$. viridis was found mainly under the loose-lying alga $F$. lumbricalis. The biomass of the species correlated negatively with the native polychaete $H$. diversicolor in the area suggesting competition between these two species (Kotta \& Kotta, 1998). Also, in the light of this study the initial disappearance of the amphipod M. affinis might be related to the introduction of M. viridis.

Sedimentation processes correlated highly with the biomass distribution of macrozoobenthos in the Väinameri (Lutt, 1985). Higher accumulation coincided with higher benthic biomasses. Besides, the presence of $F$. lumbricalis significantly increased macrozoobenthic biomasses in the area. The red algal species offered hard bottom fauna a suitable substrate otherwise absent in the study area. Intensive flow conditions coupled with the availability of a secondary substrate were favourable for the establishment of a dense population of M. edulis.

The proportion of bivalves has increased in the Väinameri during the last 30 years. A similar trend was observed in the adjacent water body, the Gulf of Riga (Cederwall et al., 1999) but also in other parts of the Baltic Sea (Cederwall \& Elmgren, 1990). In the Gulf of Riga a comparison of soft-bottom macrofauna in the 1990s with the 1960s-1980s showed that the abundance and biomass values were lowest in the 1960s, highest in the 1980s, and intermediate in the 1990s (Cederwall et al., 1999); that is the macrozoobenthos followed the changes in the nutrient concentration of the area (Ojaveer et al., 1999). As the Väinameri is periodically influenced by the nutrient rich water of the Gulf of Riga (Astok et al., 1999), the state of the Gulf of Riga has a significant role in the development of benthic communities in the Väinameri area. 


\section{ACKNOWLEDGEMENTS}

The study was carried out within the framework of the Phytobenthos Monitoring Programme financed by the Estonian Ministry of the Environment and Estonian Governmental Programmes Nos 0182578s03 and 0182579s03.

\section{REFERENCES}

Astok, V., Otsmann, M. \& Suursaar, Ü. 1999. Water exchange as the main physical process in semi-enclosed marine systems: the Gulf of Riga case. Hydrobiologia, 393, 11-18.

Atkins, S. M., Jones, A. M. \& Garwood, P. R. 1987. The ecology and reproductive cycle of a population of Marenzelleria viridis (Annelida: Polychaeta: Spionidae) in the Tay Estuary. Proc. R. Soc. Edinburgh, 92B, 311-322.

Cederwall, H. \& Elmgren, R. 1990. Biological effects of eutrophication in the Baltic Sea, particularly the coastal zone. Ambio, 19, 109-112.

Cederwall, H., Jermakovs, V. \& Lagzdins, G. 1999. Long-term changes in the soft-bottom macrofauna of the Gulf of Riga. ICES J. Mar. Sci., 56, 41-48.

Essink, K. 1999. Dispersal and development of Marenzelleria spp. (Polychaeta, Spionidae) populations in the NW Europe and The Netherlands. Helgol. Meeresunters., 52, 367-372.

Essink, K. \& Kleef, H. L. 1993. Distribution and life cycle of the North American spionid polychaete Marenzelleria viridis (Verrill, 1873) in the Ems estuary. Neth. J. Aquat. Ecol., 27, 237-246.

Essink, K., Eppinga, J. \& Dekker, R. 1998. Long-term changes (1977-1994) in intertidal macrozoobenthos of the Dollard (Ems Estuary) and effects of introduction of the North American spionid polychaete Marenzelleria cf. wireni. Senckenb. Marit., 28, 211-225.

Järvekülg, A. 1970. Väinamere põhjaloomastik. In Lääne-Eesti rannikualade loodus (Kumari, E., ed.), pp. 42-60. Valgus, Tallinn.

Kotta, J. 2000. Impact of eutrophication and biological invasions on the structure and functions of benthic macrofauna. Diss. Biol. Univ. Tartu., 63.

Kotta, I. \& Kotta, J. 1997. Changes in zoobenthic communities in Estonian waters between the 1970's and 1990's. An example from the southern coast of Saaremaa and Muuga Bay. In Proceedings of the 14th Baltic Marine Biologists Symposium (Ojaveer, E., ed.), pp. 70-79. Estonian Academy Publishers, Pärnu.

Kotta, J. \& Kotta, I. 1998. Distribution and invasion ecology of Marenzelleria viridis (Verrill) in the Estonian coastal waters. Proc. Estonian Acad. Sci. Biol. Ecol., 47, 210-217.

Kotta, J. \& Ólafsson, E. 2003. Competition for food between the introduced exotic polychaete Marenzelleria viridis and the resident native amphipod Monoporeia affinis in the Baltic Sea. J. Sea Res., 342, 27-35.

Kotta, J. \& Orav, H. 2001. Role of benthic macroalgae in regulating macrozoobenthic assemblages in the Väinameri (north-eastern Baltic Sea). Ann. Zool. Fenn., 38, 163-171.

Kotta, J., Kotta, I. \& Kask, J. 1999. Benthic animal communities of exposed bays in the outermost part of the Gulf of Finland. Proc. Estonian Acad. Sci. Biol. Ecol., 48, 107-116.

Kotta, J., Orav, H. \& Sandberg-Kilpi, E. 2001. Ecological consequence of the introduction of the polychaete Marenzelleria viridis into a shallow water biotope of the northern Baltic Sea. J. Sea Res., 46, 273-280.

Lutt, J. 1985. Bottom Sediment of the Väinameri. Institute of Geology, Academy of Sciences ESSR, Valgus, Tallinn (in Russian).

Martin, G., Torn, K., Kotta, J. \& Orav-Kotta, H. 2003. Estonian marine phytobenthos monitoring programme: preliminary results and future perspectives. Proc. Estonian Acad. Sci. Biol. Ecol., 52, 112-124. 
Ojaveer, H., Lankov, A., Eero, M., Kotta, J., Kotta, I. \& Lumberg, A. 1999. Changes in the ecosystem of the Gulf of Riga from the 1970s to the 1990s. ICES J. Mar. Sci., 56, 33-40.

Sandberg, E. 1996. Benthic Predator-Prey Relationships and Abiotic Stress - the Effect of Physical Disturbance and Oxygen Deficiency. Ph.D. dissertation, Åbo Akademi University, Åbo Akademis Tryckeri, Åbo.

TemaNord, 1996. Mapping and Monitoring of Phytobenthic Biodiversity in the Northern Baltic Sea - Background, Methods and Recommendations, 559.

Trei, T. 1970. Väinamere põhjataimestik. In Lääne-Eesti rannikualade loodus (Kumari, E., ed.), pp. 27-41. Valgus, Tallinn.

Yarvekyulg, A. 1979. Bottom Fauna in the Eastern Part of the Baltic Sea. Valgus, Tallinn (in Russian).

Zettler, M. L. 1996. Successful establishment of the spionid polychaete, Marenzelleria viridis (Verrill, 1873), in the Darss-Zingst estuary (southern Baltic) and its influence on the indigeneous macrozoobenthos. Arch. Fish. Mar. Res., 43, 273-284.

Zettler, M. L. 1997. Bibliography on the genus Marenzelleria and its geographical distribution, principal topics and nomenclature. Aquat. Ecol., 31, 233-258.

\title{
Väinamere (Läänemere kirdeosa) makrozoobentose koosluste võrdlus 1960. ja 1990.-2000. aastatel
}

\author{
Helen Orav-Kotta, Jonne Kotta ja Ilmar Kotta
}

Väinamere põhjaloomastiku kooslusi uuriti 1993.-2003. a suvel. Uurimistulemusi võrreldi 1960. aastatel kogutud andmetega. Gammarus locusta, Leptocheirus pilosus, Monoporeia affinis, Bathyporeia pilosa, Idotea baltica, Harmothoe sarsi ja Pygospio elegans on uurimisalalt viimase 30 aasta jooksul kadunud või on nende liikide arvukus oluliselt kahanenud. Vee hüdroloogiliste omaduste muutused põhjustasid G. locusta, H. sarsi ja P. elegans'i kadumise ning B. pilosa levila ahenemise. Läänemere eutrofeerumise suurenemine ei avaldanud mõju loomastiku koosluste liigilisele koosseisule, kuid suurendas põhjaloomastiku üldbiomassi neli korda. Põhja-Ameerika päritoluga hulkharjasuss Marenzelleria viridis levis Väinamerre 1995. aastal. Liik jäi uurimisala sügavamates piirkondades vähearvukalt püsima. 